\section{Consultation on} ONS's statistics work programme 2008-2012: second phase

- he Office for National Statistics (ONS) has launched the second phase of a consultation on statistical priorities. The five-year funding settlement was agreed in April 2007 as part of the Comprehensive Spending Review and covers the period from 2007/08 to 2011/12.

Phase one of the consultation took place during June and July 2007 and resulted in 90 responses being received from organisations and individuals. Details of the responses received for those who granted permission to publish their responses can be found at the address given below.

Within the link below, Annex $\mathrm{C}$ describes the current range of outputs for each National Statistics theme, the developments that are already planned, the responses to phase one consultation and ONS proposals for additional investment.

Views are invited from all ONS's stakeholders and those with an interest in its business, using the response template at Annex A. This asks just four questions and seeks replies by 30 November.

Responses will be considered by ONS and feed into its planning process. The final statistical work programme will be published in the new year. The work programme and the responses to the consultation will inform the thinking as the new Statistics Board starts to consider statistical priorities for the long term.

\section{More information}

(2) www.statistics.gov.uk/about/consultations/ ons-stat-work-prog-phase2.asp

\section{Contact}

Dave Sharp

(C) 01633812517

国 dave.sharp@ons.gsi.gov.uk

\section{Improving price statistics - the Ottawa Group}

\footnotetext{
- he Ottawa Group was set up by the UN Statistical Commission as a forum for specialist academics and practitioners to share their experiences and discuss research on crucial problems of measuring price change. The focus has been
}

on applied research particularly, though not exclusively, in the area of Consumer Price Indices (CPI).

Its first meeting was in October 1994 in Ottawa. The first paper was presented by Marta Haworth of the UK's Central Statistical Office (now Office for National Statistics (ONS)) on 'Sampling and Data Capture Issues in CPI Construction'.

It was fitting that the tenth meeting of the Group, in October this year, returned to Ottawa, 13 years and 200 papers later.

Over the years the Ottawa Group has contributed to international best practices in many key areas of CPI methodology and compilation, perhaps most significantly in relation to dealing with quality change and bias. Perhaps one of the group's biggest specific achievements with long lasting consequences has been the active participation of its members in production of the ILO Manual on Consumer Price Indices. David Fenwick, then Director of Consumer Price Indices at ONS, chaired the technical expert group who were given the task of drafting the manual and most of the chapter authors were members of the Ottawa Group.

ONS continues to be actively involved in the Ottawa Group and at the most recent meeting presented a paper on the factors that influence people's perceptions and experiences of inflation; the paper also included an overview of the interactive Personal Inflation Calculator launched on the ONS website earlier this year. This led to an interesting discussion on the technical issues relating to the calculation of inflation rates for specific categories of people, and a number of other National Statistical Offices indicated a keen interest in developing a similar interactive tool to encourage people's understanding of inflation.

ONS also presented a progress report on a project it is currently leading to develop a handbook of practical issues on CPI construction confronted by developing countries.

It also chaired a session reviewing the first ten years of the Ottawa Group and presented proposals for the future which focused on a more systematic approach to index construction and development, with the goal of moving to the production of a more coherent and inclusive family of good quality and fit-for-purpose price indices. This would encompass: standardisation and harmonisation of methodologies; progress on outstanding measurement issues (such as introducing owner-occupied housing costs); coherence with Producer Price Indices and deflators; and looking at statistical designs which will generate better value-for-money statistics.

\section{Contact}

Ben Whitestone

C 02075335926

网 ben.whitestone@ons.gsi.gov.uk

\section{National Statistician gives evidence to House of Lords Economic Affairs Committee}

( n 16 October, the National Statistician, Karen Dunnell, gave evidence to the House of Lords Economic Affairs Committee Inquiry into the economic impact of immigration, along with Paul Wiles (Chief Scientific Adviser, Home Office, responsible for statistics) and David Frazer (Head of Statistics, Department for Work and Pensions). This followed the submission of written evidence to the Committee by a number of organisations including the Office for National Statistics, the Bank of England, the Statistics Commission and a several local authorities. Further details are available at the address given below.

Committee members asked questions about statistics about migrants, how they might be improved, and the extent of crossdepartmental co-operation in developing migration statistics to meet user needs. A full transcript of the hearing can be accessed from the House of Lords website at the address given below.

\section{More information}

Written submissions

www.parliament.uk/parliamentary committees/lords_economic_affairs/ eaffwrevid.cfm

\section{Transcript of hearing}

(ब) www.parliament.uk/parliamentary committees/lords_economic_affairs.cfm

\section{Contact}

Peter Goldblatt

(C) $02075335265 / 01329812622$ peter.goldblatt@ons.gsi.gov.uk 


\section{Intangible investment and productivity in the Pre- Budget Report}

\footnotetext{
- he Pre-Budget Report (PBR) was announced on 9 October by the Chancellor of the Exchequer. In
} his speech to the House of Commons, he referred to new analysis suggesting that UK businesses might be investing in skills, innovation and intellectual property proportionally as much as those in the United States. Full details of the PBR can be obtained from the address given below. The analysis, published as a Treasury Economic Working Paper alongside the PBR, investigates the consequences for a range of macroeconomic variables, including productivity, of treating business spending on knowledge as investment.

This report (see details below) summarises the findings of a Treasuryfunded project led by Professor Jonathan Haskel, co-authored with Mauro Giorgio Marrano and Gavin Wallis, as reported in the June edition of Economic \& Labour Market Review.

The authors of the report use information from a number of ONS and independent sources to evaluate how much UK companies could be investing in knowledge. Based on these data and a number of assumptions, the analysis concludes that:

- business investment in 2004 would have been about double the official measure. Investment in intangibles was $£ 123$ billion, compared with tangible investment of $£ 96$ billion

- the value of measured market sector output would have been higher by about 6 per cent in 1970 and 13 per cent in 2004

- instead of the ratio of nominal business investment to market sector output falling since 1970, it would have been rising

- growth in labour productivity and capital deepening would have been higher than previously estimated

- total factor productivity growth would not have slowed down since 1990, as it appears on current measures, but would have been picking up, and

- comparing the results with the US suggests that the share of intangible investment in market sector output is similar in both countries

These results imply a number of challenges to the way National Accounts, in the UK and abroad, measure and record a range of business expenditures.
While traditional measurement techniques may underestimate the importance of investment in intangibles in driving productivity growth in recent years, National Accounts need to comply with international standards and guidelines to ensure consistency and comparability. ONS is responding to these challenges by playing an active role, in the UK and internationally, in driving forward this agenda:

- in the Blue Book 2007, ONS revised its software investment estimates by improving its estimates of own-account software expenditure

- ONS is also about to produce a preliminary Satellite Account treating R\&D expenditures as investment, thereby leading on the implementation of the ongoing revision to the SNA. ONS contributes to the Eurostat and OECD working groups that will set out the implementation guidance

- ONS plays a key advisory role to the academic team refining its estimates of intangible investment through detailed industry analysis and discussions with business representatives

\section{More information}

Pre-Budget report

(凶) www.hm-treasury.gov.uk/pbr_csr/report pbr_csr07_repindex.cfm

Treasury Economic Working Paper

(2) www.hm-treasury.gov.uk/pbr_csr/documents/ pbr_csr07_intangible.cfm

\section{Contact}

Tony Clayton

C 02075335913

凶tony.clayton@ons.gsi.gov.uk

\section{SNA93 revision and its implementation}

\section{-}

his year's OECD National Accounts

Working Party meeting was held in

Paris between October 2 and 3. The

SNA93 revision process (SNA93 Rev. 1) and its implementation were the two most important topics discussed at this meeting.

SNA93 Rev. 1 will include all 44 issues agreed by the United Nations Statistical Commission. It will be published in two volumes: Volume 1, to be published in 2008 , will cover chapters 1 to 17 , while Volume 2, to be published in 2009 , will cover chapters 18 to 27 .

Feedback from the worldwide consultation on draft chapters has led SNA93 Rev. 1 to proceed with care on a few issues such as: treatment of research and development (R\&D) as capital; cost of capital for market producers to be voluntary; cost of capital for non-market producers where further research is needed; capitalisation of military expenditure as recommended; and undertaking more research on $\mathrm{R} \& \mathrm{D}$.

In EU Member states, the revised ESA95 will cover all recommendations agreed at international level. Drafting of chapters begins in January 2008. A completed report will be submitted to the European Commission for approval in March 2009. All EU countries are expected to adopt the revised ESA95 by 2014; the same applies to OECD countries. Special features will be the implementation by all countries of R\&D and pensions satellite accounts.

In readiness for implementation, Eurostat is asking Member countries to properly inform and raise awareness about the ESA95 revision project, and National Statistical Institutes to conduct impact assessments of the revision of ESA95 to evaluate resources needed for the priority project and to give an idea of the potential impact on main aggregates to political users as early as possible. For its part, Eurostat will organise three meetings: two on the transmission timetable to be held between September 2008 and February 2009, and a meeting for economists, macroeconomic statisticians and national accountants to be held in 2009. Public consultation of users will take place in mid-2008.

Other issues discussed were: the OECD handbooks on measuring capital (revised), on measuring intellectual property and on measurement of volume output of health and education; and revisions analysis and transmission of data.

Some countries shared their knowledge and experience in compiling estimates of household non-financial assets, satellite accounts for R\&D and environmental accounts.

For its part, the Office for National Statistics has now begun making preparations towards the eventual implementation of ESA95 Rev. 1.

\section{Contact}

Walter Mkandawire

C 02075336067

walter.mkandawire@ons.gsi.gov.uk 